\title{
TRADE POLICY AND THE AMERICAN INCOME DISTRIBUTION
}

\author{
James C. Hartigan and Edward Tower*
}

\section{Introduction}

$\mathrm{P}$ REVIOUS studies of the effects of U.S. tariffs and quotas on U.S. real income and its distribution have concluded that these effects are minimal. Moreover, this conclusion has emerged from both partial equilibrium ${ }^{1}$ and general equilibrium ${ }^{2}$ approaches. However, most of these studies assumed labor to be the only variable factor. This study combines a general equilibrium methodology with a significant degree of disaggregation by using the 83 sector United States input-output table and a linear programming approach ${ }^{3}$ to assess the impact of the 1967 structure of U.S. tariffs and quotas on the American functional income distribution. We conclude that when all factors are perfectly mobile, the effects on aggregate real income and its distribution are much greater than previously found, and these effects are highly sensitive to the degree of mobility assumed. Section II presents the critical assumptions of the model, and contrasts them with those of the other models. Section III contains a discussion of the data, and section IV draws our conclusions.

Received for publication January 18, 1980. Revision accepted for publication October 2, 1981.

* SUNY/Buffalo and Duke University, respectively.

The authors are indebted to Albert Walderhaug for teaching them about input-output conventions and providing unpublished data and to Bob Conrad for helping to develop solutions to data problems. Thanks also go to John Dutton, Isaac Ehrlich, Dave Evans, Hal Fried, Ed Mitchell, Ed Ray, Dave Richardson, Forrest Smith, Bob Stern, Vlad Treml, and Tom Willett.

1 See Baldwin (1976a, 1976b); Baldwin, Mutti, and Richardson (1980); Cline, Kawanabe, Kronsjo, and Williams (1978); Magee (1972); and Stern (1964).

2 Brown and Whalley (1980); Clements (1979); Deardorff, Stern, and Baum (1977); Deardorff, Stern, and Greene (1979); Klein and Su (1979); and Whalley (1980).

${ }^{3}$ Linear programming was used by Evans (1972); Lage (1970), and Williams (1978) to model the tariffs for Australia, Japan and Canada, respectively, but all authors focused on changes in sectoral production rather than on income distribution and welfare.

\section{The Model ${ }^{4}$}

In the model, there are 83 sectors consisting of 63 traded and 20 nontraded goods, and in each sector primary and intermediate inputs are used in fixed proportions. Factors are fixed in aggregate supply, goods are absorbed into final consumption in fixed proportions, and all factors of production share common tastes. All product and factor prices are perfectly flexible within the United States to assure full employment (except when the marginal product of a factor falls to zero) and a flexible exchange rate maintains the balance of trade at its 1967 level. The world prices of all tradables are assumed to be fixed, and each traded good is subject to international transport costs derived from the input-output table.

Because foreign and domestic production are assumed to be sectorally undifferentiated, imports can supplant an entire domestic industry. This contrasts with the assumption of imperfect substitutability between foreign and domestic production in each sector of the general equilibrium models of Deardorff, Stern and Baum (1977); Deardorff, Stern and Greene (1979); Brown and Whalley (1980); and Whalley (mimeograph). Furthermore, they postulate endogenous pricing of traded goods. In these general equilibrium models a composite primary factor input is formed from constant elasticity of substitution (CES) aggregates of homogeneous labor and capital, and domestic and foreign products within the same product category form a composite CES aggregated intermediate input. These composite primary and intermediate inputs are combined according to fixed coefficients production functions. Deardoff et al. and Brown and

\footnotetext{
${ }^{4}$ An appendix describing the model in far greater detail is available from the authors upon request. Our model is a special case of that developed by Evans (1972). For a very clear and careful discussion of the logic of linear programming (LP) models see his paper.
} 
Whalley specify a different elasticity of substitution for each product class, which is assumed to be identical across all countries for each product class. An additional difference between this paper and those of Deardorff et al. is that the latter assume an exogenous money wage rate, permit nominal expenditure to vary only by changes in tariff revenue, and focus on changes in employment. Real wages change because the prices of traded goods change, but the essentially fixed nominal expenditure combines with the fixed money wage to preclude the real wage from changing sufficiently to clear the labor market. This can generate unemployment. The authors could have extended their model by positing monetary or fiscal policy that removed the slack in the labor market. Brown and Whalley (1980) and Whalley (mimeograph) permit wage and rent changes to clear the factor market just as we do. Any important difference in the conclusions of this model and those of the other general equilibrium models is likely to be a result of the above differences in assumptions. Strict comparability is not possible, however, since the above make no statement about functional income distribution.

The papers that have disaggregated labor have taken a short-run perspective in that they have not permitted the full simultaneous determination of product or factor prices across sectors of the economy: wage rates are assumed to be fixed and the supply curve of value added is flat. This includes Baldwin (1976a, 1976b); Baldwin, Mutti, and Richardson (1980); and Cline et al. (1978). Moreover, these also focus on employment changes, rather than functional income distribution.

This paper considers five applications of the basic model. In our first set of simulations, natural resources, land and reproducible capital are perfect substitutes for one another, and we do not distinguish between various types of labor, simply assuming that if one man's wage is twice that of another in the base period, then one man-year of the former's labor is equivalent to two man-years of the latter's labor. These aggregates are referred to as capital and labor, and we suppose that both factors are perfectly mobile within the U.S. economy. The results of these simulations are summarized in table 1.

In our second set of simulations, we assume that reproducible capital, land and each of the various depletable assets (ores, coal, and petroleum) in extractive industries 5-10 are distinct and there is no capacity for substitution between them. Similarly, labor is broken down into five categories: farmers, less skilled labor, skilled craftsmen, scientists and professionals, and non-farm managers, and again, there is no ability to substitute one factor for another. Furthermore, we assume that all of these factors are mobile within the U.S. economy, although each depletable asset is used by only one input-output industry. The results of these simulations are summarized in table 2.

The third set of simulations is identical to the

Tabit 1.-Tht Erfects of Alternative Tariffs Whin Labor and Capital Are Both Homogeneous and Perfectly Mobile Internaliy a.t.c.

\begin{tabular}{|c|c|c|c|c|c|c|c|c|c|}
\hline Simulation: & 1.1 & 1.2 & 1.3 & 1.4 & 1.5 & 1.6 & 1.7 & 1.8 & 1.9 \\
\hline U.S. Tariff & () & 50 & 100 & 150 & 200 & 0 & 100 & 100 & 200 \\
\hline Foreign Tariff & 100 & 100 & 100 & 100 & 100 & 0 & 0 & 200 & 200 \\
\hline U.S. $Y^{\prime \prime}$ & 108.50 & 107.33 & 100.00 & 99.86 & 99.82 & 126.47 & 124.05 & 99.84 & 99.82 \\
\hline Labor's $Y$ & 130.05 & 118.63 & 100.00 & 99.62 & 99.71 & 127.80 & 76.61 & 98.40 & 96.81 \\
\hline Capital's $Y$ & 68.34 & 86.26 & 100.00 & 100.32 & 100.02 & 124.00 & 212.44 & 102.53 & 105.42 \\
\hline Importing Industries ${ }^{1, . .}$ & 43 & 24 & 25 & 1 & 1 & 61 & 38 & 1 & 1 \\
\hline Exporting Industries & 2 & 2 & 38 & 1 & 1 & 2 & 2 & 1 & 1 \\
\hline Producing Industries & 40 & 59 & 83 & 83 & 83 & 22 & 45 & 83 & 83 \\
\hline$\theta^{\prime}$ with Fixed $W^{k}$ & 66.01 & 80.62 & 100.00 & 100.10 & 100.06 & 59.37 & 119.72 & 104.09 & 105.04 \\
\hline$\theta$ with Fixed CPI ${ }^{\mathrm{h}}$ & 87.35 & 93.31 & 100.00 & 99.90 & 99.95 & 73.18 & 81.87 & 102.57 & 101.86 \\
\hline
\end{tabular}

"All terms in the lables are explained at the base of the table where the are tirst introduced.

"All figures except those denoted with" are expressed as a percentage of the corresponding bate year entry. For example. an entry of 50 for the $(\mathrm{s}$. tariff mean that all U.S. tariffs and the tariff equivalents of all U.S. import quotas have heen cut to $5 \%$; of their base period levels.

The real incomen of each factor are calculated by assuming that all tariff and indired husines tat revenue collected by the United States. an well as the balance of trade deficit. is distributed in proportion to factor incomes.

" $Y$ denotes real expenditure (real income).

- The terms importing. exporting. and producing industres refer to the number of industrien in each imulation that are importers. exporters. and producers respectively.

$\theta$ is the dollat price of foreign exchange.

: $U$ is the money wage rate

(1') denoter the U.S. Comune Price Index. 
Table 2.-The Effects of Alternative Tariffis When Labor and Capital. Are Both Heterogeneous and Perfectly Mobile Internally

\begin{tabular}{|c|c|c|c|c|c|c|c|c|c|}
\hline Simulation: & 2.1 & 2.2 & 2.3 & 2.4 & 2.5 & 2.6 & 2.7 & 2.8 & 2.9 \\
\hline U.S. Tariff & 0 & 50 & 100 & 150 & 200 & 0 & 100 & 100 & 200 \\
\hline Foreign Tariff & 100 & 100 & 100 & 100 & 100 & 0 & 0 & 200 & 200 \\
\hline U.S. Y & 106.13 & 105.50 & 100.00 & 99.76 & 99.76 & 118.89 & 118.22 & 99.93 & 99.68 \\
\hline Professionals ${ }^{`} Y$ & 19.19 & 34.76 & 100.00 & 100.06 & 100.35 & 26.95 & 107.23 & 118.99 & 116.58 \\
\hline Managers $^{{ }^{j}} Y$ & 112.20 & 185.50 & 100.00 & 97.09 & 94.46 & 12.15 & 0 & 50.17 & 43.40 \\
\hline Craftsmen's ${ }^{\mathrm{k}} Y$ & 118.98 & 101.00 & 100.00 & 99.70 & 99.66 & 65.11 & 64.62 & 101.48 & 99.79 \\
\hline Workers" ${ }^{`} Y$ & 167.03 & 130.22 & 100.00 & 100.58 & 101.40 & 150.22 & 81.29 & 109.83 & 122.42 \\
\hline Farmers $Y$ & 349.55 & 361.33 & 100.00 & 92.42 & 85.07 & 0 & 0 & 0 & 38.40 \\
\hline$R$ Capital's $s^{m} Y$ & 72.55 & 75.39 & 100.00 & 99.99 & 100.21 & 186.78 & 223.93 & 108.28 & 99.91 \\
\hline Land's $Y$ & 0 & 0 & 100.00 & 102.85 & 105.58 & 0 & 0 & 8.68 & 10.93 \\
\hline Resources' ${ }^{n} Y$ & 9.72 & 14.93 & 100.00 & 115.87 & 133.09 & 0 & 0 & 74.06 & 199.16 \\
\hline Labor`s $Y$ & 125.11 & 122.64 & 100.00 & 99.55 & 99.35 & 85.00 & 64.52 & 96.58 & 100.15 \\
\hline Importing Industries & 29 & 23 & 25 & 6 & 6 & 55 & 34 & 5 & 4 \\
\hline Exporting Industries & 5 & 5 & 38 & 7 & 7 & 4 & 4 & 6 & 8 \\
\hline Producing Industries & 56 & 62 & 83 & 82 & 82 & 29 & 49 & 83 & 83 \\
\hline$\theta$ with Fixed Craftsmen's $W$ & 80.75 & 98.54 & 100.00 & 100.00 & 100.00 & 128.05 & 139.33 & 102.48 & 104.33 \\
\hline$\theta$ with Fixed Workers $W$ & 57.52 & 76.42 & 100.00 & 99.12 & 98.27 & 55.50 & 110.76 & 94.69 & 85.04 \\
\hline$\theta$ with Fixed CPI & 97.31 & 97.69 & 100.00 & 99.93 & 99.87 & 82.25 & 83.06 & 103.99 & 104.31 \\
\hline
\end{tabular}

Professionals indicates scientists and professionals.

' Managers denotes nonfarm managers.

h Craftsmen are skilled craftsmen.

I Workers denotes less skilled labor.

" $R$ Capital is reproducible capital.

"Resources are extractive resources.

second except that we variously constrain $99 \%$, $75 \%, 50 \%$ and $25 \%$ of the reproducible capital and land in each industry to be immobile to other industries, arguing that these successively less stringent restrictions on mobility represent successively longer time horizons, so that we have results ranging from those which are relevant descriptions of very short-run to very long-run equilibrium. These simulations are described in table 3.

The fourth set of simulations extends the analysis of immobility to the various skill groups of

Table 3.- The Effects of Zero U.S. Tariffs When Labor and Capital Are Both Heterogeneous,

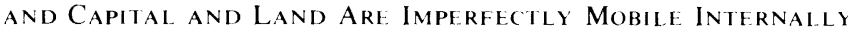

\begin{tabular}{|c|c|c|c|c|c|c|c|c|c|c|c|}
\hline Simulation: & 3.1 & 3.2 & 3.3 & 3.4 & 3.5 & 3.6 & 3.7 & 3.8 & 3.9 & 3.10 & 3.11 \\
\hline U.S. Tariff & 100 & 0 & 0 & 0 & 0 & 0 & 0 & 0 & 0 & 0 & 0 \\
\hline $\begin{array}{l}\text { Foreign Tariff } \\
\text { / } / \text { of Capital \& }\end{array}$ & 100 & 100 & 100 & 100 & 100 & 100 & 0 & 0 & 0 & 0 & 0 \\
\hline Land Mobile & 100 & 1 & 25 & 50 & 75 & 100 & 1 & 25 & 50 & 75 & 100 \\
\hline U.S. $Y$ & 100.00 & 100.19 & 102.55 & 103.86 & 104.90 & 106.13 & 100.54 & 105.02 & 109.55 & 114.15 & 118.89 \\
\hline Professionals $Y$ & 100.00 & 28.95 & 86.89 & 61.59 & 49.95 & 19.19 & 28.17 & 82.26 & 31.74 & 30.43 & 26.95 \\
\hline Craftsmen's $Y$ & 100.00 & 79.24 & 75.06 & 111.24 & 123.77 & 118.98 & 70.72 & 8.34 & 64.62 & 67.01 & 65.11 \\
\hline Workers $Y$ & 100.00 & 38.11 & 131.77 & 163.10 & 170.29 & 167.03 & 21.24 & 113.08 & 147.30 & 150.06 & 150.22 \\
\hline Farmers $Y$ & 100.00 & 0 & 0 & 145.59 & 211.28 & 349.55 & 0 & 0 & 0 & 0 & 0 \\
\hline$R$ Capital's $Y$ & 100.00 & 180.10 & 136.02 & 106.40 & 100.37 & 72.55 & 225.43 & 189.18 & 165.43 & 176.08 & 186.78 \\
\hline Land's $Y$ & 100.00 & 0 & 0 & o & 0 & 0 & 0 & 0 & 0 & 0 & 0 \\
\hline Resources` $Y$ & 100.00 & 3.33 & 0 & 0 & 0 & 9.72 & 0 & 0 & 0 & 0 & 0 \\
\hline $\begin{array}{l}\text { Labor's } Y \\
\text { Importing }\end{array}$ & 100.00 & 59.73 & 86.43 & 103.94 & 108.69 & 125.11 & 36.56 & 62.41 & 89.71 & 83.29 & 85.00 \\
\hline $\begin{array}{l}\text { Exporting } \\
\text { Industries }\end{array}$ & 38 & 31 & 8 & 5 & 6 & 5 & 35 & 13 & 7 & 4 & 4 \\
\hline Producing & & & & & & & & & & & \\
\hline $\begin{array}{c}\text { Industries } \\
\theta \text { with Fixed }\end{array}$ & 83 & 83 & 71 & 69 & 68 & 56 & 82 & 68 & 63 & 62 & 29 \\
\hline $\begin{array}{l}\text { Craftsmen's } W \\
\theta \text { with Fixed }\end{array}$ & 100.00 & 106.88 & 122.57 & 86.50 & 78.39 & 80.75 & 109.07 & 924.57 & 126.02 & 123.19 & 128.05 \\
\hline Workers $W$ & 100.00 & 222.22 & 69.82 & 58.99 & 56.98 & 57.52 & 363.33 & 68.21 & 55.27 & 55.00 & 55.50 \\
\hline$\theta$ with Fixed CPI & 100.00 & 85.01 & 92.75 & 97.29 & 98.36 & 97.31 & 77.51 & 78.55 & 82.33 & 82.42 & 82.25 \\
\hline
\end{tabular}


Table 4.-The Effects of Zero U.S. Tariffs When labor and Capital Are Both Heterogeneous and all Factors Are Imperfectly Mobile Internally

\begin{tabular}{|c|c|c|c|c|c|c|c|c|c|c|c|}
\hline Simulation: & 4.1 & 4.2 & 4.3 & 4.4 & 4.5 & 4.6 & 4.7 & 4.8 & 4.9 & 4.10 & 4.11 \\
\hline U.S. Tariff & 100 & 0 & 0 & 0 & 0 & 0 & 0 & 0 & 0 & 0 & 0 \\
\hline Foreign Tariff & 100 & 100 & 100 & 100 & 100 & 100 & 0 & 0 & 0 & 0 & 0 \\
\hline U.S. $Y$ & 100.00 & 100.10 & 101.61 & 103.12 & 104.63 & 106.13 & 100.37 & 105.33 & 109.83 & 114.33 & 118.89 \\
\hline Professionals $Y$ & 100.00 & 66.28 & 34.03 & 34.92 & 35.56 & 19.19 & 6.16 & 27.42 & 24.51 & 26.40 & 26.95 \\
\hline Managers' $Y$ & 100.00 & 25.47 & 60.20 & 65.52 & 61.47 & 112.20 & 174.82 & 0 & 11.36 & 11.76 & 12.15 \\
\hline Workers' $Y$ & 100.00 & 171.76 & 169.65 & 170.76 & 171.36 & 167.03 & 108.97 & 144.25 & 145.04 & 147.64 & 150.22 \\
\hline Farmers' $Y$ & 100.00 & 150.50 & 151.96 & 324.63 & 323.80 & 349.55 & 0 & 0 & 0 & 0 & 0 \\
\hline$R$ Capital's $Y$ & 100.00 & 69.71 & 71.67 & 74.51 & 77.26 & 72.55 & 129.78 & 157.27 & 167.10 & 176.87 & 186.78 \\
\hline Land's $Y$ & 100.00 & 94.94 & 109.13 & 0 & 0 & 0 & 0 & 0 & 0 & 0 & 0 \\
\hline Resources $Y$ & 100.00 & 0.59 & 8.32 & 8.29 & 8.28 & 9.72 & 0 & 0 & 0 & 0 & 0 \\
\hline $\begin{array}{l}\text { Labor's } Y \\
\text { Importing }\end{array}$ & 100.00 & 116.39 & 117.48 & 119.75 & 120.37 & 125.11 & 86.41 & 79.41 & 81.37 & 83.24 & 85.00 \\
\hline $\begin{array}{l}\text { Industries } \\
\text { Exporting }\end{array}$ & 25 & 24 & 29 & 28 & 28 & 29 & 27 & 53 & 54 & 54 & 55 \\
\hline $\begin{array}{l}\text { Industries } \\
\text { Producing }\end{array}$ & 38 & 32 & 6 & 6 & 6 & 5 & 34 & 6 & 4 & 4 & 4 \\
\hline $\begin{array}{l}\text { Industries } \\
\theta \text { with Fixed }\end{array}$ & 83 & 83 & 82 & 82 & 82 & 56 & 82 & 81 & 81 & 81 & 29 \\
\hline $\begin{array}{l}\text { Craftsmen's } W \\
\theta \text { with Fixed }\end{array}$ & 100.00 & 74.29 & 76.09 & 76.07 & 76.07 & 80.75 & 457.97 & 124.24 & 128.05 & 128.05 & 128.05 \\
\hline Workers' $W$ & 100.00 & 55.34 & 56.21 & 56.20 & 56.20 & 57.52 & 67.50 & 55.11 & 55.50 & 55.50 & 55.50 \\
\hline$\theta$ with Fixed CPI & 100.00 & 97.96 & 97.97 & 97.97 & 97.97 & 97.31 & 77.90 & 82.39 & 82.25 & 82.25 & 82.25 \\
\hline
\end{tabular}

labor. Thus, we consider $99 \%, 75 \%, 50 \%$ and $25 \%$ of all factors of production to be immobile to other industries. These simulations are summarized in table 4.

An important development in the evolution of studies concerned with comparative advantage has been the role of human capital. ${ }^{5}$ This paper explicitly acknowledges that contribution by performing a set of simulations in which less skilled labor is the only mobile factor. The other factors are characterized by varying degrees of immobility due to sector specific human capital. Professionals, managers, and craftsmen are assumed to embody training costs that preclude immediate sectoral reallocation, whereas farmers are assumed to require major geographic reallocation. Thus, table 5 presents simulations that are identical to the fourth set except for the perfect mobility of less skilled labor.

In each simulation, all revenues from tariffs and indirect business taxes, as well as revenue equal to the balance of payments deficit, are distributed to the factors of production as a proportional income subsidy, and each factor of production is assumed to spend all of its disposable

\footnotetext{
' This evolution is considered in detail in Hartigan (1981a). A misinterpretation of the Deardorff et al. model in that article is corrected in the present paper.
}

income. Throughout the paper we refer to this measure of income and expenditure, divided by the price of the consumption bundle, as real income, and denote it by $Y$ in the tables.

\section{Data ${ }^{6}$}

The 1967 flow input-output table used for this study was obtained from Walderhaug (1977). It includes competitive intermediate imports of good $i$, which are valued at foreign ports, as an input into the production of its counterpart domestic good $i$. We eliminated this element, and entries in the transportation, wholesale and retail trade, and insurance industries associated with importing it. Had we not done so, imports into each industry would have been proportional to domestic output in alternative simulations of the model. The direct coefficients matrix was then calculated so that the domestic cost of producing a unit of domestic good $i$ was unity.

The base period output of each good was computed as the value presented in the input-output table net of competitive intermediate imports at foreign port value, and the transportation, duty,

${ }^{\circ}$ A detailed appendix describing the data manipulations necessary to implement the model is available from the authors upon request. 
TRADE POLICY AND U.S. INCOME DISTRIBUTION

Table 5.-The Effects of Zero U.S. Tariffs When less Skilled labor Is Perfectly Mobile and All Other factors Are Imperfectly Mobile

\begin{tabular}{|c|c|c|c|c|c|c|c|c|c|c|c|}
\hline Simulation: & 5.1 & 5.2 & 5.3 & 5.4 & 5.5 & 5.6 & 5.7 & 5.8 & 5.9 & 5.10 & 5.11 \\
\hline U.S. Tariff & 100 & 0 & 0 & 0 & 0 & 0 & 0 & 0 & 0 & 0 & 0 \\
\hline Foreign Tariff & 100 & 100 & 100 & 100 & 100 & 100 & 0 & 0 & 0 & 0 & 0 \\
\hline \% Mobility & 100 & 1 & 25 & 50 & 75 & 100 & 1 & 25 & 50 & 75 & 100 \\
\hline U.S. $Y$ & 100.00 & 100.14 & 102.12 & 103.53 & 104.88 & 106.13 & 100.30 & 105.51 & 109.82 & 114.75 & 118.89 \\
\hline Professionals' $Y$ & 100.00 & 0 & 0 & 0 & 0 & 19.19 & 0 & 0 & 0 & 0 & 26.95 \\
\hline Managers $Y$ & 100.00 & 433.63 & 221.63 & 162.57 & 165.90 & 112.20 & 521.68 & 214.18 & 164.93 & 94.47 & 12.15 \\
\hline Craftsmen`s $Y$ & 100.00 & 40.76 & 42.54 & 104.51 & 108.05 & 118.98 & 18.81 & 12.74 & 25.69 & 45.38 & 65.11 \\
\hline Workers $Y$ & 100.00 & 41.68 & 123.54 & 160.88 & 161.70 & 167.03 & 16.43 & 107.65 & 123.90 & 137.81 & 150.22 \\
\hline Farmers` $Y$ & 100.00 & 0 & 113.52 & 363.60 & 377.29 & 349.55 & 0 & 0 & 0 & 0 & 0 \\
\hline$R$ Capital's $Y$ & 100.00 & 73.80 & 93.95 & 61.61 & 61.96 & 72.55 & 71.19 & 133.07 & 146.29 & 168.56 & 186.78 \\
\hline Land's $Y$ & 100.00 & 0 & 0 & 0 & 0 & 0 & 0 & 0 & 0 & 0 & 0 \\
\hline Resources $Y$ & 100.00 & 19.24 & 0 & 4.73 & 11.44 & 9.72 & 6.22 & 0 & 0 & 0 & 0 \\
\hline Labor's $Y$ & 100.00 & 115.09 & 107.83 & 126.89 & 128.75 & 125.11 & 116.89 & 92.50 & 92.25 & 88.17 & 85.00 \\
\hline \multicolumn{12}{|l|}{ Importing } \\
\hline Industries & 25 & 28 & 32 & 29 & 30 & 29 & 28 & 49 & 52 & 52 & 55 \\
\hline \multicolumn{12}{|l|}{ Exporting } \\
\hline Industries & 38 & 31 & 6 & 6 & 5 & 5 & 34 & 11 & 4 & 4 & 4 \\
\hline \multicolumn{12}{|l|}{ Producing } \\
\hline Industries & 83 & 83 & 78 & 77 & 77 & 56 & 81 & 70 & 70 & 71 & 29 \\
\hline \multicolumn{12}{|l|}{$\theta$ with Fixed } \\
\hline Craftsmen s $W$ & 100.00 & 168.80 & 207.27 & 88.26 & 86.87 & 80.75 & 267.27 & 556.59 & 292.20 & 175.81 & 128.05 \\
\hline \multicolumn{12}{|l|}{$\theta$ with Fixed } \\
\hline Workers` $W$ & 100.00 & 183.98 & 74.05 & 59.45 & 59.10 & 57.52 & 374.24 & 70.81 & 63.64 & 59.33 & 55.50 \\
\hline$\theta$ with Fixed CPI & 100.00 & 76.94 & 92.09 & 96.49 & 96.57 & 97.31 & 61.90 & 76.81 & 79.07 & 81.05 & 82.25 \\
\hline
\end{tabular}

and insurance costs associated with them. Stocks of primary factors of production were computed as the product of base period output and the direct primary input coefficients.

Labor and capital were disaggregated using information from the Bureau of Labor Statistics industry-occupation matrix (1977), corporation income tax returns (U.S. Dept. of the Treasury, 1967), and Walderhaug (1978).

Walderhaug (1979) provides data on imports at domestic port value by each industry into final demand. This includes insurance and freight, but not duty. Exports were obtained from Walderhaug (1977). Each industry was labelled an exportable or an importable, if exports net of imports were positive or negative. If both exports and imports were close to zero, the industry was labelled a nontradable.

Domestic absorption of each good $i$ was calculated as the sum of domestic consumption, investment, and government expenditure from both domestic and foreign sources. Final demand coefficients for each industry $i$ were computed as domestic absorption of good $i$ divided by total domestic absorption.

U.S. ad valorem tariffs were calculated by summing the tariff revenue collected from competitive intermediate imports and imports into final demand, and dividing this revenue by the sum of competitive intermediate imports and final demand imports at domestic port valuation. The average tariff on intermediate noncompetitive imports is $0.2 \%$, so we ignored it.

Information on tariffs imposed by the 18 major trading partners of the United States came from Baldwin (1976b), for dutiable exports. These tariffs include the variable agricultural levies of the European Economic Community (EEC), and are those prevailing on January 1, 1973. Baldwin reveals that dutiable U.S. exports comprise $58.88 \%$ of total U.S. exports. To obtain 1967 foreign tariffs, Baldwin's figures were adjusted upward using Finger's (1974) statement that the Kennedy-Round negotiations yielded a $35 \%$ cut on $55 \%$ of all dutiable imports. Estimates of ad valorem equivalents of U.S. quotas and voluntary export restraints were also specified.

World prices of tradables were calculated using information from Walderhaug $(1977,1979)$ on international transport margins, and the tariff and nontariff barriers discussed above, so that all domestic prices in the base period simulation were unity.

Alternative trade policies were modelled by multiplying all tariffs in the study by a factor $\alpha$, where $\alpha$ varies from 0 to 2 in increments of 0.5 
for the United States and 1.0 for foreigners. For those industries $(16-19,37)$ in which the rent of U.S. quotas is deemed to accrue to foreigners, world import prices to the United States were adjusted by multiplying the base period rent by $\alpha$.

\section{Conclusions}

All of the following conclusions are made with respect to the 1967 base period.

\section{A. General Conclusions from All Five Tables}

Conclusions in subsection A refer to all five tables except where indicated.

1. With perfect factor mobility in the long run, no matter whether the factors are homogeneous or heterogeneous (tables 1 and 2), U.S. trade barriers protect U.S. capital at the expense of U.S. labor, and foreign trade barriers protect U.S. labor at the expense of U.S. capital. These inferences are made by removing one protective structure while holding the other constant, and observing how real factor incomes change. This result is surprising. The two sector, two country Heckscher-Ohlin model, with identical and homothetic tastes in both countries, predicts that the domestic and foreign tariffs would have identical effects on relative factor prices in the United States. Similarly, prohibitive American tariffs would have precisely the same effects on resource allocation as prohibitive foreign tariffs in any model. Thus, we expected to find that U.S. and foreign tariffs protected the same factor of production within the United States. When either tariff structure was made prohibitive in the two factor case, our simulations generated a wage of zero for American labor (not shown). That the return to one factor should fall to zero is consistent with the fixed proportions nature of the model, and that labor is the factor which is harmed is consistent with Leontief's finding that labor is America's plentiful factor. This creates a presumption that higher tariffs by either country will be detrimental to American labor. However, Hartigan`s (1981b) regressions of tariffs (plus the tariff equivalents of import quotas and voluntary export restraints) on capital intensity demonstrate that both the United States and its trading partners tend to protect industries which are capital intensive according to U.S. factor re- quirements, and this is consistent with our results.

2. Trade policy affects income radically. This is because

a. Foreign and domestic production are perfect substitutes. Thus imports can entirely replace a domestic industry. This permits a high degree of specialization. It also means that the United States can expand exports in a sector to a large multiple of that occurring in the base year, making it possible for a change in one tariff to have a significant impact on income distribution. Except when multiple solutions occur, the number of exporting industries cannot be greater than the number of factors of production. These are 2 in the homogeneous case, 12 in the heterogeneous case, and 95 when a percentage of each industry's capital stock is sector specific.

b. The fixity of input coefficients in production and of the coefficients of absorption into final consumption reduces the elasticity of the economy's derived demands for factors. This combined with fixed aggregate factor supplies means that a change in the domestic prices of tradables will tend to produce a large change in factor prices.

3. There is some nonmonotonicity present in the real returns of factors of production with respect to changes in the degree of protection. The easiest case to discuss is that of farmers when the United States unilaterally reduces its trade barriers. Consider livestock and livestock products; other agricultural products; forestry and fishery products; and agricultural, forestry, and fishery services. These are the only industries that employ either land and/or farmers. The land input-output coefficients are 0.05544 , $0.10645,0.13744$, and 0.00000 , respectively. The farmer input-output coefficients are 0.03380 , $0.06548,0.00000$, and 0.02791 , respectively. These industries are protected by ad valorem tariffs and tariff equivalents of $0.175,0.084$, 0.012 , and 0.000 , respectively. When barriers are cut by $50 \%$, livestock and livestock products, initially protected by high barriers, are replaced entirely by imports. The most land intensive industry, forestry and fishery products, contracts its production to approximately $15 \%$ of the base year. This releases a significant amount of land, which is not completely absorbed by the expan- 
sion of other agricultural products. Thus, land's rental rate is zero. Other agricultural products, which is most intensive in the use of farmers, expands the most, driving up the farmers 'wage rate to $354.7 \%$ of that in the base period. ${ }^{7}$ The complete removal of U.S. trade impediments leads to marginal increases in the production of forestry and fishery products, and agricultural, forestry, and fishery services, and marginal contraction in other agricultural products. Land's rental rate is still zero, and the slight decline in the production of the most farm labor intensive industry generates a decline in the demand for farmers that is not counterbalanced by an increase in the output of agricultural, forestry, and fishery services. Thus, farmers' real wage falls to $354.1 \%$ of that in the base period. Because the input-output coefficient for each factor of production is so small, a slight change in the structure of product prices leads to highly magnified changes in factor prices.

4. U.S. real income is a decreasing function of both U.S. and foreign trade barriers. Since there are no terms of trade effects, this is expected.

5. In the base period simulation, multiple equilibria were obtained, all with equal values for the objective function (U.S. real expenditure out of factor incomes), i.e., the domestic price plane was tangent to a facet of the production possibility frontier, but the value of U.S. real expenditure varied with the amount of tariff and indirect business tax revenue collected, so that U.S. welfare is indeterminate. Thus, the base period simulation to which we refer is the one for which each sector's output was constrained to that actually observed in 1967.

6. The welfare corresponding to any configuration of tariffs is higher the more factor mobility and generally higher the more substitutability we assume, i.e., the more flexible is the economy. This is because the production gains from trade will be larger, the less is the curvature of the production possibility frontier. ${ }^{8}$

\footnotetext{
${ }^{7}$ Note that the figures for farmers' wages in this paragraph refer to real wages, not real incomes, since the latter include the proportional income subsidy.

8 Thus we expect that for a given trade policy and degree of factor mobility U.S. real income will be highest in table 3 and lowest in table 4. This is always true for unilateral barrier elimination. However, reciprocal free trade generates some
}

7. Decreases cause larger welfare changes than increases in either tariff structure. This is because some tariffs are close to zero, so that when tariffs are multiplied by a common factor, the economy specializes in importing goods with low domestic tariffs, and exporting goods with low foreign tariffs. On the other hand, lower U.S. tariffs encourage U.S. specialization in those commodities in which a comparative advantage exists, generating substantial efficiency gains. Similarly, lower foreign tariffs increase some export prices significantly, and thereby permit much more efficiency through increased specialization in exportables for which profitability has increased.

8. With flexible relative prices, any attempt to fix the nominal return of a factor whose real return is declining is likely to lead to currency depreciation.

9. Unilateral and reciprocal tariff cuts always appreciate the dollar when the monetary authority freezes the value of the CPI. That this should be true for unilateral reductions is surprising, but this possibility has been noted by Johnson (1966). The appreciation of the dollar in this model can be explained in part by the decline in the prices paid to foreigners for the five goods for which the United States imposes quotas and the rents accrue to foreigners; and by the expansion of the sectors from which the United States exports in free trade to substantial multiples of the base period values. ${ }^{9}$

10. It is interesting to note the exports in which the economy concentrates under various trade policies. They are noted only for the homogeneous case for brevity. In simulations 1.1 and 1.2 they are other agricultural products and mis-

anomalies due to sectorally nonuniform business taxes. Compare for example, 3.8, 4.8, and 5.8 in which 3.8 generated the lowest level of welfare but had the highest degree of factor mobility. The value of the objective function of the linear program always has the correct ranking. However, indirect business tax revenue in 3.8 was substantially lower than in the corresponding simulations due to a different structure of production.

9 Simulations performed with each sector's exports constrained to not exceed that sector's base year gross exports by a multiple of three always generated a devaluation of the dollar (not shown). This suggests that the ability of the economy to specialize in a small number of exportables, which can expand at a fixed world price, is the cause of the appreciation of the dollar. The expansion of the domestic production of these sectors and its attendant effect on income distribution is discussed in subsection B.9. 
cellaneous fabricated textile products. In 1.4, 1.5, 1.8 , and 1.9 it is aircraft and parts. In 1.6 and 1.7 it is tobacco manufactures and miscellaneous fabricated textiles. ${ }^{10}$

\section{B. Conclusions from the Long-run Heterogeneous Model}

1. Scientists and professionals benefit from either unilateral or reciprocal increases in tariffs and a unilateral foreign freeing of trade, and are harmed by unilateral American or reciprocal freeing of trade.

2. Nonfarm managers benefit from a unilateral trade liberalization, and are harmed by any other change in trade policy.

3. A unilateral barrier reduction by the United States benefits skilled craftsmen, as does a unilateral foreign tariff increase. Any other policy is detrimental to them.

4. Less skilled labor benefits from any change in trade policy except a unilateral foreign barrier elimination. In fact, the simulations imply that the effect of U.S. trade policy in 1967 was to minimize the income of this group.

5. Farmers gain by a unilateral U.S. tariff reduction, but any other change in trade policy is detrimental to them.

6. Reproducible capital is harmed by a unilateral U.S. barrier reduction and reciprocal barrier increases. It benefits from a reciprocal freeing of trade, and any unilateral foreign impediment change. The effect of a unilateral U.S. barrier increase is unclear.

7. Land is helped by a unilateral U.S. barrier increase, but is harmed by any other change in trade policy.

8. Extractive resources experience qualitatively identical effects to those of land, except they gain from reciprocal barrier increases.

9. The structure of production that produces these distributional effects will be discussed for unilateral U.S. barrier elimination. The focus will be on export industries, since these have expanded the most.

When the U.S. unilaterally frees trade, it ex-

\footnotetext{
${ }^{10}$ We are currently exploring the issue of effective protection in more detail.
}

ports from 5 sectors. These are other agricultural products (1.5), miscellaneous fabricated textile products $(56.0)$, chemicals and selected chemical products (2.4), rubber and miscellaneous plastics products (4.4), and metal containers (10.5), where parentheses denote production expressed as a multiple of the base period output. Other agricultural products contains farmers as $84.9 \%$ of base period labor value added. Since the 3 U.S. agricultural industries are 7 times as capital intensive as the U.S. economy, and capital's real income declined, and land was in excess supply because livestock products were not produced, farmers' real income increased substantially. Miscellaneous fabricated textile products contains less skilled labor as $79.6 \%$ of base period labor value added. This industry's expansion largely explains less skilled labor's gains. Skilled craftsmen's gain is largely explained by the expansion of rubber and miscellaneous plastics products and metal containers which employ them as $48.4 \%$ and $60.6 \%$ of base period labor value added, respectively. Extractive resource income declines because 4 out of 5 industries under this rubric do not produce, the domestic needs for these products being met by imports. This contributes to the decline in the real income of reproducible capital, as these industries are highly reproducible capital intensive, and there is not a sufficiently significant expansion of a capital-intensive industry to counterbalance it. Scientists and professionals suffer devastating losses because 3 industries with large input coefficients for them do not produce or significantly curtail production. These are radio, television, and communication equipment; electronic components and accessories; and aircraft and parts. Nonfarm managers receive modest gains because they are used moderately in 4 out of 5 exporting industries, which are in the manufacturing sector.

\section{Conclusions from the Short-run Heterogeneous Model}

The trade policies considered are unilateral U.S. and reciprocal barrier elimination under varying degrees of factor immobility. Table 3 considers immobility of land and reproducible capital. In table 4 , all factors of production are subject to immobilities, while table 5 permits less skilled labor to be the only perfectly mobile fac- 
tor. ${ }^{11}$ High degrees of immobility refer to the short run, with successively less stringent restrictions on mobility representing longer time horizons. Perfect mobility is the long run.

1. The most surprising conclusion from the tables 3,4 , and 5 is how few regularities there are. In table 3, for example, the elimination of the U.S. tariff benefits nonfarm managers the most when capital and land are either very mobile or very immobile, and benefits skilled craftsmen the most when capital and land mobility is intermediate. Moreover, U.S. free trade can either benefit or harm managers, craftsmen, less skilled labor, farmers, labor in the aggregate and reproducible capital, depending on the degree of capital and land mobility assumed.

2. Less skilled labor generally gains more from unilateral or reciprocal tariff elimination the longer the time horizon, i.e., the higher the factor mobility considered (except for one anomaly in table 3 , and unilateral elimination in table 4). ${ }^{12}$

Moreover, the degree of factor mobility makes a substantial quantitative difference, with reciprocal free trade reducing less skilled labor's real income by $79 \%$ in the short run and raising it by $50 \%$ in the long run, and with unilateral cuts lowering it by $62 \%$ in the short run and raising it by $67 \%$ in the long run, when land and capital are

\footnotetext{
11 The distribution of the returns to the sector specific factors in the three versions of the short run was based on the assumption that capital is the least mobile productive factor. and should bear the entire cost of the immobility in an industry. Once the return to capital within an industry fell to zero. the other factors in that industry, subject to mobility constraints, shared in that excess immobility cost in proportion to the rental rates of their mobile counterparts. Note that the ratio of the real income of skilled craftsmen to that of workers will equal the ratio of their wages only when neither of these factors are subject to mobility constraints. This is because mobility costs are netted from gross incomes to determine the incomes reported in the tables.

12 An analogous result occurs in a simple version of our model. Suppose that labor and capital in the United States combine to produce two outputs. This generates a two faceted production possibility frontier (PPF) with the laborintensive exportable on the horizontal axis and the capitalintensive importable on the vertical. Assume that production is initially at the kink in the PPF with the tariff-inclusive price line having a slope between that of the two constraints, and the world relative price line is steeper than both constraints. Moreover, assume that both goods in the United States are absorbed in fixed proportions, with the United States initially an exporter of the labor-intensive good. If the United States unilaterally eliminates its tariff, labor's income will fall in the short run, so long as capital's mobility constraint is binding, but will rise in the long run when this mobility constraint ceases to bind.
}

the immobile factors. Furthermore, which factors are deemed immobile is of substantial quantitative importance. With unilateral liberalization, less skilled labor's real income rises by $72 \%$ in the short run when all factors are immobile, and falls by $58 \%$ in the short run when less skilled labor is the only perfectly mobile factor. For reciprocal liberalization in the short run, the figures are an increase of $9 \%$ and a decrease of $84 \%$, respectively. For less skilled labor, the short-run scenarios with land and capital being the immobile factors are similar to less skilled labor being the only perfectly mobile factor.

3. Despite the sensitivity of the results to the time horizon and the selection of immobile factors, some conclusions can be made about the effects of freeing trade. Owners of land and extractive resources, as well as scientists and professionals, will be harmed by either policy of trade liberalization. Except for the very short run, a reciprocal barrier elimination helps capital. Reciprocal free trade hurts farmers and craftsmen under all time horizons. Finally, less skilled labor may lose significantly in the short run, but will always gain significantly in the long run.

Can it be that this last result explains some of the conflict between the economists who take a long-run view of free trade and the politician or labor leader who takes a shorter view?

\section{REFERENCES}

Baldwin, Robert E., U.S. Tariff Policy: Formation and Effects, U.S. Department of Labor, Bureau of International Labor Affairs, Office of Foreign Economic Research, Discussion Papers on International Trade, Foreign Investment, and Employment (1976a).

- 'Trade and Employment Effects in the United States of Multilateral Tariff Reductions," American Economic Review Proceedings 66 (May 1976b), 142-148.

Baldwin, Robert E., John H. Mutti, and J. David Richardson, "Welfare Effects on the United States of a Significant Multilateral Tariff Reduction," Journal of International Economics 10 (Aug. 1980), 405-423.

Brown, Fred, and John Whalley, "Tariff Cutting Proposals in the Tokyo Round: A General Equilibrium Analysis," Economic Journal 90 (Dec. 1980), 838-866.

Clements, Kenneth W., “Protection and Commercial Policy: Experiments with a General Equilibrium Econometric Model," Empirical Economics 4 (2) (1979), 135-148.

Cline, William R., Noboru Kawanabe, T.O.M. Kronsjo, and Thomas Williams, Trade Negotiations in the Tokyo Round: A Quantitative Assessment (Washington, D.C.: Brookings Institution, 1978).

Deardorff, Alan V., Robert M. Stern, and Christopher F. Baum, "A Multi-Country Simulation of the Employ- 
ment and Exchange Rate Effects of Post-Kennedy Round Tariff Reductions," in N. Akrasanee et al. (eds.), Trade and Employment in Asia and the Pacific (Honolulu: University Press of Hawaii, 1977).

Deardorff, Alan V., Robert M. Stern, and Mark N. Greene, "The Implications of Alternative Trade Strategies for the United States," in D. B. H. Denoon (ed.), The New International Economic Order: A U.S. Response (New York: New York University Press, 1979). Original version reprinted in The 1978 Midyear Review of the Economy, Hearings before the Joint Economic Committee, 95 th Congress, second session, part 2, July 12, 13, and 18, 1978.

Evans, H. David, A General Equilibrium Analysis of Protection (Amsterdam: North-Holland Publishing Company, 1972).

Finger, J. Michael, "GATT Tariff Concessions and the Exports of Developing Countries: United States Concessions at the Dillon Round," Economic Journal 84 (Sept. 1974), 566-575.

Hartigan, James C., "The U.S. Tariff and Comparative Advantage: A Survey of Method," Weltwirtschaftliches Archiv 117 (Heft 1, 1981), 65-109.

"Does Factor Content Determine Protection?" Southern Economic Journal 48 (July 1981), 144-148.

Johnson, Harry G., "A Model of Protection and the Exchange Rate," Review of Economic Studies 33 (Apr. 1966), 159-163.

Klein, Lawrence R., and Vincent Su, "Protectionism: An Analysis from Project LINK," Journal of Policy Modeling 1 (Jan. 1979), 5-35.

Lage, Gerald M., "A Linear Programming Analysis of Pro- tection," Western Economic Journal 8 (June 1970), 167-185.

Magee, Stephen P., "The Welfare Effects of Restrictions on U.S. Trade," Brookings Papers on Economic Activity 3 (3, 1972), 645-701.

Stern, Robert M., "The U.S. Tariff and the Efficiency of the U.S. Economy," American Economic Review. Proceedings 54 (May 1964), 459-470.

U.S. Department of Labor, Bureau of Labor Statistics, "National/State Industry-Occupation Matrix" (computer tape) (1977).

U.S. Department of the Treasury, Internal Revenue Service, Corporation Income Tax Returns (1967).

Walderhaug, Albert J., Revised Input-Output Tables for the United States: 1967, U.S. Department of Commerce, Bureau of Economic Analysis, Bureau of Economic Analysis Staff Paper No. 39 (June 1977), 1-60.

, Employment and Employee Compensation in the 1967 Input-Output Study. U.S. Department of Commerce, Bureau of Economic Analysis Staff Paper No. 34 (June 1978), 1-64.

unpublished data on noncompetitive imports in the 1967 U.S. Input-Output Study, U.S. Department of Commerce, Bureau of Economic Analysis (1979).

Whalley, John, "An Evaluation of the Recent Tokyo Round Trade Agreement Through a General Equilibrium Model of World Trade Involving Major Trading Areas," University of Western Ontario (mimeograph) (Apr. 1980).

Williams, James R., The U.S.-Canadian Tariff and Canadian Industry: A Multi-Sectoral Analysis (Toronto: University of Toronto Press, 1978). 